\title{
Irrigation of Greenhouse Crops
}

\author{
Georgios Nikolaou ${ }^{1, *}$, Damianos Neocleous ${ }^{2} \mathbb{D}$, Nikolaos Katsoulas ${ }^{1} \mathbb{B}$ and \\ Constantinos Kittas ${ }^{1}$ \\ 1 Department of Agriculture Crop Production and Rural Environment, School of Agricultural Sciences, \\ University of Thessaly, Fytokou Str., 38446 Volos, Greece; nkatsoul@gmail.com (N.K.); ckittas@uth.gr (C.K.) \\ 2 Department of Natural Resources and Environment, Agricultural Research Institute, 1516 Nicosia, Cyprus; \\ d.neocleous@ari.gov.cy \\ * Correspondence: gnicolaounic@gmail.com; Tel.: +30-24-2109-3249
}

Received: 29 November 2018; Accepted: 29 December 2018; Published: 15 January 2019

\begin{abstract}
Precision agricultural greenhouse systems indicate considerable scope for improvement of irrigation management practices, since growers typically irrigate crops based on their personal experience. Soil-based greenhouse crop irrigation management requires estimation on a daily basis, whereas soilless systems must be estimated on an hourly or even shorter interval schedule. Historically, irrigation scheduling methods have been based on soil or substrate monitoring, dependent on climate or time with each having both strengths and weaknesses. Recently, plant-based monitoring or plant reflectance-derived indices have been developed, yet their potential is limited for estimating the irrigation rate in order to apply proper irrigation scheduling. Optimization of irrigation practices imposes different irrigation approaches, based on prevailing greenhouse environments, considering plant-water-soil relationships. This article presents a comprehensive review of the literature, which deals with irrigation scheduling approaches applied for soil and soilless greenhouse production systems. Irrigation decisions are categorized according to whether or not an automatic irrigation control has the ability to support a feedback irrigation decision system. The need for further development of neural networks systems is required.
\end{abstract}

Keywords: accumulated radiation method; feedback irrigation system; fuzzy control system; irrigation dose; precision irrigation; phyto-sensing; soilless culture; transpiration; water use efficiency

\section{Introduction}

The concept of "precision agriculture" is used to define technologies that support customized agricultural practices aimed at higher efficiency and a lower impact on the environment [1]. Greenhouse production systems decrease crop water requirements by as much as $20 \%$ to $40 \%$ compared to open field cultivation; however, growers routinely apply more irrigation water than the estimated water consumption [2-4]. Irrigation practices are generally based on the personal perspective of the grower; i.e., irrigation without monitoring the soil or plant water status [5]. Considering the number of different plant species grown in prevailing greenhouse environments, the types of substrate and container sizes, field and soil characteristics, and the different irrigation systems, it becomes obvious why irrigation scheduling becomes complex if it is to be achieved with any level of precision [6-8]. Therefore, an accurate short term estimation of crop water requirements in protected cultivation are a prerequisite for optimal irrigation scheduling; as evapotranspiration $\left(E T_{C}\right)$ could occur so rapidly that water loss can cause plant damage before wilting symptoms become visible $[9,10]$. Irrigation management is typically expected to achieve maximum water supply for plant growth and production, with soil or substrate water content being maintained close to field capacity [11].

Even in soilless cultivation systems, irrigation represents a very large and potentially important loss of nutrients and a source of environmental pollution (i.e., drain to waste hydroponics systems) as a 
surplus of $20 \%$ to $50 \%$ of the plant's water uptake in each irrigation cycle is often recommended [12-16]. Indeed, annual use of irrigation water ranges from 150 to $200 \mathrm{~mm}$ (e.g., leafy vegetable) in soil-based greenhouse crops to 1000 to $1500 \mathrm{~mm}$ in soilless-grown (e.g., Solanaceae, cucurbits) [11]. For container nursery production, as cited by Fulcher et al. [17], those values could be as high as $2900 \mathrm{~mm}$.

Considering the scarcity of water resources combined with the operational energy irrigation costs, maintaining the sustainable use of water is a major water-climate policy challenge since excessive irrigation results in low water use efficiency, increases in runoff and contributes to higher $\mathrm{CO}_{2}$ emissions [18-20]. Several institutions have worked to improve water use in irrigation, developed various models of water efficiency, reducing the environmental problems associated with irrigation in order to mitigate severe structural water deficits, yet these models are not commercialized $[4,21]$.

This paper presents a review of the literature dealing with irrigation of greenhouse crops. The necessity, the advantages and the limitations of each irrigation approach used are discussed in relation to different greenhouse types and the ability of an irrigation controller unit to support a feedback irrigation decision system.

\section{Background}

The exact time and volume of irrigation are probably the most important factors for efficient irrigation management and saving water, and these in turn also improve the productivity and quality of crops grown in the greenhouse [22,23]. This is especially true as the high potential efficiency of fertigation (i.e., irrigation combined with fertilization) has become a routine cultural practice, therefore the terms "irrigation" and "fertigation" are often used interchangeably [24-27]. Yet, irrigation management of substrate-based greenhouse crops still requires much more accurate control than for the same crop grown in soil, taking into account that substrates have very little nutrient buffering capacity [28].

Soilless growth systems in readily made artificial media commonly use organic (i.e., coconut coir, peat moss, pine bark) or inert substrates (i.e., perlite, rockwool, vermiculite); with substrate volume at approximately 10 to $40 \mathrm{~L} \mathrm{~m}^{-2}$ as is the case of rockwool or perlite slabs [29,30]. Horticultural production has historically been increasingly based on those ready-made substrates produced on an industrial scale with unique characteristics such as a limited cation exchange and low buffering capacity, good water permeability and adequate aeration [31]. Compared to soil cultivation systems, soilless growth systems are superior for plant growth as less energy is required by plants to extract water at field capacity, therefore experiencing a lower risk of oxygen deficiency [32,33]. In the same manner, all containerized production systems can be considered as hydroponic (i.e., soilless growth system) since they consist of an artificial root zone aimed at optimizing water and nutrient availability [34]. However, the restricted root volume may negatively affect the supply of nutrients to the plants as the water in the substrate may be rapidly decreased [32,35-37]. In addition, changes are induced in air and water retention characteristics of organic and inorganic substrates when they are used for longer periods than one growing season [38,39]. Therefore, according to Deepagoda et al. [29], a porous media should preferably be inert to prevent chemical and biological interactions.

Irrespective of the type of greenhouse cultivation system used (i.e., soil or soilless), irrigation scheduling should be managed (I) to supply plants with the volume of water equal to the volume of transpired water for maintaining crop productivity, (II) to overcome the differences in water discharge achieving high water uniformity (III) to move excessive salts towards the rooting system, avoiding soil salination $[30,40]$. Even in the latter case, for greenhouse cultivation systems there is always a risk of erroneous choices in the matching irrigation supply to crop evapotranspiration, as it may be affected by sudden changes in outside weather conditions or the use of climate control systems such as heating and ventilation [41]. That is another reason why for open hydroponic systems the main irrigation strategy is to supply nutrient solutions, with a surplus of $30 \%$ to $50 \%$ of the water uptake by the plants [14]. 
The leaching requirement in greenhouse soil-grown cultivation can be estimated based on irrigation water salinity and crop salt tolerance following FAO [42] as below:

$$
L R=\frac{E C_{i w}}{5 E C_{e}-E C_{i w}},
$$

where $L R$ is the minimum leaching requirement needed to control salts within the tolerance $E C_{e}$ of the crop; $E C_{i w}$ is the electrical conductivity of the irrigation water applied $\left(\mathrm{dS} \mathrm{m}^{-1}\right)$; and, $E C_{e}$ the average soil salinity tolerated by the crop as measured on a soil saturation extract $\left(\mathrm{dS} \mathrm{m}^{-1}\right)$.

However, as cited by Ben-Gal et al. [43], traditional guidelines for the calculation of the crop-specific leaching requirement is imprecise due to failure to consider soil type, climate, or salinity-induced reduction in plant transpiration. Such omissions could possibly result in underestimating actual leaching and over-estimation of leaching requirements.

Micro-irrigation is often promoted as a technology that can increase the application efficiency of water, and improve crop production and quality. The sub irrigation system also applies for the production of many ornamental hydroponic crops. However, the tendency for salts to build up in the upper portion of the root zone represents a drawback [44,45]. Harmanto et al. [46] working with soil-based greenhouse tomatoes (Solanum lycopersicum) in a tropical environment indicated that by applying drip irrigation, the water savings inside the greenhouse could be as much as $20 \%$ to $25 \%$ higher compared to an open field drip irrigated farming system.

For scheduling irrigation in soil or soilless greenhouses, it is essential to estimate the crop evapotranspiration and, according to the soil or substrate, the irrigation dose. In addition, as cited in Incrocci et al. [16], the irrigation dose of container growing medium could be estimated based on water potential or volumetric water content, with the use of soil moisture sensors. In the meantime, the adoption of soil moisture monitoring in vegetables has been restricted by means of sensor accuracy and price as well as labor required for installation, removal, and collection of readings [7]. A recent review by Bianchi et al. [47] summarized the four macro-groups of soil water potential devices and their operational characteristics.

According to Cahn and Johnson [7], an advantage of tension thresholds is the lesser influence by soil texture in comparison to volumetric moisture thresholds. Even so, as cited by Nikolaou et al. [48], sensors that estimate dielectric capacitance or dielectric permittivity of substrates (e.g., time domain reflectometry, frequency domain) have a propensity to be more reliable for soilless culture systems, as opposed to sensors measuring water availability through the matric potential such as the tensiometers.

According to Baille [49], in the short-term, decision level irrigation can be triggered based either on greenhouse microclimate or on soil/substrate moisture status. Irrigation scheduling based on direct or indirect measurement of plant water status and plant physiological responses to drought by using plant-based methods was comprehensively reviewed by several authors [50,51]. The different methods of irrigation scheduling in greenhouses is summarized below (Table 1). 
Table 1. Greenhouse irrigation methods for soil and soilless greenhouse cultivation systems.

\begin{tabular}{|c|c|c|c|c|}
\hline Scheduling Irrigation & Based on & Method/Device Use & Decisions Made & Reference \\
\hline Time clock based & Time & Irrigation controllers & Irrigation frequency & {$[52,53]$} \\
\hline \multirow{6}{*}{ Climate monitoring } & \multirow{5}{*}{ Evapotranspiration } & Lysimeters & Determine evapotranspiration $\left(E T_{C}\right)$ & [54-56] \\
\hline & & Class A Pan & $\begin{array}{c}\text { Determine reference } \\
\text { evapotranspiration }\left(E T_{O}\right)\end{array}$ & {$[57,58]$} \\
\hline & & Reduce Class A Pan & $\begin{array}{c}\text { Determine reference } \\
\text { evapotranspiration }\left(E T_{O}\right)\end{array}$ & {$[2,59]$} \\
\hline & & Atmometer & $\begin{array}{c}\text { Determine reference } \\
\text { evapotranspiration }\left(E T_{O}\right)\end{array}$ & [15] \\
\hline & & Evapotranspiration models & Crop water used & {$[9,41]$} \\
\hline & Solar radiation & Pyranometer & Irrigation frequency & {$[60,61]$} \\
\hline \multirow{6}{*}{ Soil or substrate monitoring } & \multirow{2}{*}{ Water potential } & Tensiometer & $\begin{array}{l}\text { Irrigation frequency/dose } \\
\text { mainly for soil cultivations }\end{array}$ & [62] \\
\hline & & $\begin{array}{l}\text { Electrical resistance sensor } \\
\text { (e.g., gypsum blocks) }\end{array}$ & Irrigation frequency for soil & [62] \\
\hline & Volumetric water content & $\begin{array}{c}\text { Dielectric sensor } \\
\text { (e.g., time domain reflectometry, frequency domain) }\end{array}$ & $\begin{array}{l}\text { Irrigation frequency } \\
\text { for soilless and soil cultivations }\end{array}$ & [62-64] \\
\hline & Electrical conductivity & Electrical conductivity sensor & Irrigation frequency for soilless cultivation & [65-67] \\
\hline & Physical properties & Mathematic formula & $\begin{array}{l}\text { Irrigation dose/frequency } \\
\text { for soilless and soil cultivations }\end{array}$ & $\begin{array}{l}{[23,51,65,} \\
68]\end{array}$ \\
\hline & Percentage of drainage & Mathematic formula, weighting devices & $\begin{array}{l}\text { Irrigation volume and frequency } \\
\text { based on trial and error for soilless }\end{array}$ & {$[69,70]$} \\
\hline \multirow{6}{*}{ Phyto-sensing } & Leaf water potential & Pressure chamber & Irrigation timing & [33] \\
\hline & Stomata resistance & Diffusion porometer & Irrigation timing & [33] \\
\hline & Canopy temperature & Infrared thermometry & Irrigation timing & {$[33,71,72]$} \\
\hline & Flow on water in the stem & Heat balance sap flow sensor & Irrigation timing/detect water shortages & {$[33,73,74]$} \\
\hline & Changes in stem diameter & Dentrometer & Irrigation timing & [33] \\
\hline & Crop reflectance & $\begin{array}{l}\text { Sensing system equipment and plant reflectance indices } \\
\text { (e.g., photochemical reflectance index, normalized } \\
\text { difference vegetation index) }\end{array}$ & Detect water stress & {$[51,75]$} \\
\hline
\end{tabular}




\subsection{Monitoring Irrigation in Greenhouse Crops}

Irrigation scheduling may have an impact on crop water productivity, affecting fruit yield and quality as well [76-78]. However, the targeted performance of a crop is largely situational; as irrigation might also be used as a tool for increasing water use efficiency, for maximizing yield or economic return [79].

For soil-based greenhouse cucumber (Cucumis sativus), Alomran [77] indicated that applying deficit irrigation at specific crop stages with $80 \% E T_{C}$ (i.e., decrease irrigation water up to $40 \% E T_{C}$ ) is the most appropriate irrigation strategy for high crop water productivity and yield. For greenhouse tomatoes, partial root drying resulted in a water savings of $50 \%$, but negatively affected the total fruit and total dry mass. However, the considerable savings of water could make partial root drying feasible in areas where water is scarce and expensive [80].

For soilless greenhouse cucumber, between transplanting and flowering, irrigation should be scheduled so as to induce slight water stress and increase root growth, while tomatoes should be stressed for a longer period (i.e., about three weeks) in order to set the first and second trusses [81]. In addition, several authors $[53,60,82-84]$ indicated that increasing the irrigation intervals in soilless culture with the same daily amount of water applied positively influenced crop growth and production and minimized the outflow of water and nutrients from the greenhouse into the environment. However, that is not always the case, because results are often crop and substrate specific, and are also dependent on the experimental conditions and the limiting growth factor(s) [85].

A more rational approach for optimizing irrigation is through automatic irrigation controllers. Therefore, irrigation management approaches may be categorized according to the ability of a controller unit to support a feedback system [86]. Irrigation operations are often automated by using timers, specialized controllers, or computer control [87]. In the simplest form of automation in an "open loop irrigation control system", no measurements of the system outputs are used to modify the inputs and irrigation is based on preset time intervals (i.e., time clock scheduling) $[86,88,89]$. In a "feedback based irrigation closed-loop control system", the system provides growers with output data in real time (i.e., percentage of drainage, plant water status) which are evaluated in order to reschedule or perform irrigation. In a "feed forward irrigation control system" water uptake is predicted by using growth and transpiration models [14,71]. In addition, computerized-controlled irrigation systems can utilize a range of data to achieve accurate delivery of water according to crop requirements [71]. These systems are often mentioned as a fuzzy-logic control system, artificial intelligent system or multicriterion decision-making system. They are gaining importance because of their inherent ability to judge alternative scenarios for the selection of the best alternative which may be further analyzed before implementation [90].

\subsection{The Soil/Substrate Physical Properties and the Irrigation Dose}

Evapotranspiration rates depend on greenhouse environmental conditions, and are also affected by the water supply to the roots [91]. For scheduling irrigation, hydraulic properties and water content dependence on substrate suction must be known as they influence the water movement and retention in the substrate [91-93]. Water retention curves or moisture characteristic curves relate the water content in a specific substrate to the matric potential at a given tension or height [94]. Different kinds of substrates, as Fields et al. [95] indicated, have different water retention curves (Figure 1). 


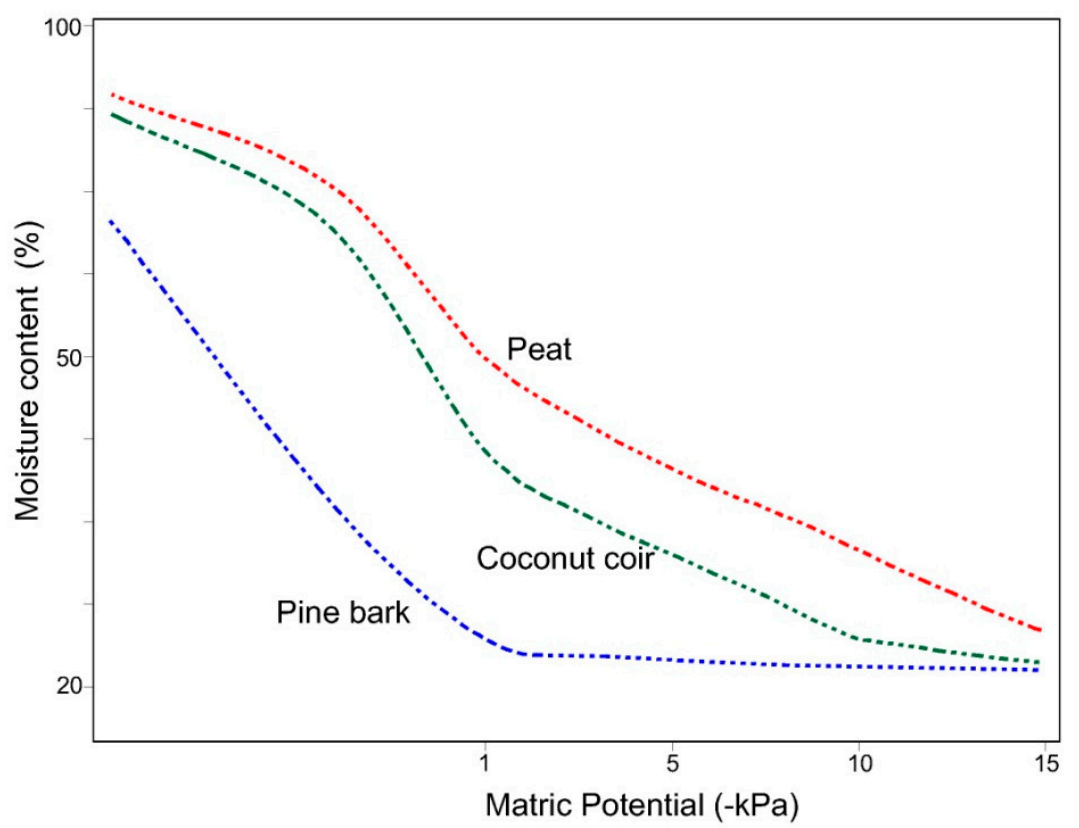

Figure 1. Moisture retention curves of peat, coconut coir and aged pine bark substrate components. Data adapted from [95].

From Figure 1, we can observe that the easily available water content (i.e., water released between 1 and $5 \mathrm{kPa}$ ) in coir is higher in comparison to pine bark; therefore, the crop may absorb more available water, reducing the need for applying a high frequency irrigation program. In addition, a taller container proportionately holds less water, as a percentage of water content by volume. Irrigation should take into account indices related to substrate availability of water, to container geometry and to specific substrate characteristics [64]. In general, water held by tensions higher than $10 \mathrm{kPa}$ are considered unavailable to the crop, and water held between 5 to $10 \mathrm{kPa}$ tensions are referred to as the substrate water buffer capacity. The available water in the container can be estimated according to Baudoin as follows [96]:

$$
A W \text { cont. }=+0.64 A W+0.30 P-67 h+4.1,
$$

where $A W$ is the water that is available in a specific substrate as obtained from the water release curve (\%); $P$ represents the substrate porosity; $h$ is the height of the container (m).

However, according to Raviv [97], water and nutrient availability to plants depends on the actual moisture flux from the medium to the plant roots rather than on the water volume in the container. By measuring water contents at different pressure heads, the soil water retention function can be determined. However, the unsaturated hydraulic conductivity measurement is often difficult as it may require expensive equipment $[91,94,98]$. The reason is because substrates containing predominantly organic components decompose during crop production cycles resulted in changes in air to water ratios. Additionally, shrinkage and compaction of substrates generates problems with watering, hydration, and generally leads to worsening the air to water relationship $[99,100]$. In the same way, hydraulic conductivity of rockwool and similar substrates is high when well-watered, but declines drastically as it dries out and plants experience a water deficit [101].

Mavrogianopoulos [65] proposed a simple equation for the estimation of the irrigation dose based on substrate characteristics as below:

$$
Q=\frac{Y \times W_{W} \times N}{(1-d r)}
$$

where $Q$ is the irrigation dose $\left(\mathrm{L} \mathrm{slab}^{-1}\right) ; Y$ is the water holding capacity of the substrate inside the slab $\left(\mathrm{L} \mathrm{slab}^{-1}\right) ; W_{w}$ is the percentage of the water holding capacity that is easily available water (\%); $N$ 
represents a critical percentage of the easily available water that when reached, irrigation should start (i.e., typical values between $5 \%$ to $35 \%$ ); $d r$ is the percentage of drainage (\%).

According to the same author, the substrate water holding capacity could be estimated by weighing it when dry, then filling it up with water for up to $24 \mathrm{~h}$ to complete the wetting process, draining up to $12 \mathrm{~h}$, and reweighing it. The difference in weight is the water holding capacity, in $\mathrm{kg} \mathrm{slab}^{-1}$ or L slab ${ }^{-1}$; however, this procedure should be repeated at different stages throughout plant growth.

In addition, another equation for estimating the irrigation dose was proposed by Katsoulas [82], taking into account the crop transpiration rate plus an extra amount of water for leaching purposes. This method simply reflects the substrate influence on crop water uptake, but requires frequent measurements of crop's transpiration rates.

$$
\begin{gathered}
E=\frac{T_{r}}{(1-D)}, \\
\operatorname{Tr}=\zeta R G_{0}, \\
\zeta=\frac{K_{c} \tau \alpha}{\lambda},
\end{gathered}
$$

where $E$ is the amount of water applied in $\left(\mathrm{Kg} \mathrm{m}^{-2}\right)$; $\operatorname{Tr}$ is the crop transpiration $\left(\mathrm{kg} \mathrm{m}^{-2}\right) ; K_{c}$ is the species-specific crop coefficient; $\tau$ is the greenhouse radiation transmission coefficient; $R G_{0}$ is the solar radiation measured outside the greenhouse $\left(\mathrm{Kj} \mathrm{m}^{-2}\right) ; a$ is the evaporation coefficient; $\lambda$ is the latent heat of vapourization of water $\left(\mathrm{kJ} \mathrm{kg}^{-1}\right)$; and $D$ is the drainage rate equal to $50 \%$ of irrigation water apply.

For greenhouse soil-based cultivation the amount of water which is "available" for root water uptake is defined as the amount of soil water between field capacity (i.e., soil matric pressure -10 or $-33 \mathrm{kPa}$ ) and the permanent wilting point (i.e., $-1500 \mathrm{kPa}$ ) expressed in $\mathrm{m}$ of water per $\mathrm{m}$ of soil depth. However, besides its use in irrigation management, field capacity is not an adequate soil physical quantity to assess soil water availability to crops, as a considerable ( $10 \%$ to $50 \%)$ fraction of transpired water is acquired from the soil at water contents above field capacity [102].

The most common values for typical soil texture classes are cited by Snider [103] in Table 2.

Table 2. Average values of available water holding capacity of the main soil texture groups (cm of water per cm of soil). Data adapted from [103].

\begin{tabular}{cccc}
\hline Common Name & Field Capacity & Wilting Point & Available Water \\
\hline Sandy soils & $0.06-0.20$ & $0.02-0.08$ & $0.04-0.12$ \\
Loamy soils & $0.23-0.27$ & $0.10-0.12$ & $0.13-0.15$ \\
Clayey soils & $0.28-0.40$ & $0.13-0.25$ & $0.15-0.18$ \\
\hline
\end{tabular}

When the available soil moisture within the rooting zone has attained a predefined level of available water (i.e., the management allowable deficit-MAD), irrigation is triggered. The estimation of MAD is difficult because it depends on plant species and the evaporative conditions [104]. In general, the MAD can be calculated as a percentage of the available water, usually $30 \%$ to $50 \%$ in soil and $10 \%$ in soilless cropping systems. Then, the irrigation dose can be calculated by multiplying the MAD with a coefficient with typical values from 1.15 to 2, to account for water application uniformity and salinity. Typically, the frequency of irrigation can be estimated when the accumulated daily $E T_{C}$ for the periods between irrigations approaches the MAD [96]. In line with this, the irrigation frequency of greenhouse soil cultivations can be estimated by dividing the readily available water with crop evapotranspiration [68]. 
Zeng et al. [23], working with drip-irrigated greenhouse soil cultivation of muskmelon, defined the irrigation dose by measuring the soil water content daily. When the water content was reduced to the irrigation start point, then the irrigation amount was decided:

$$
\begin{gathered}
I r=\frac{\gamma \times h \times \theta_{f c} \times(g 1-g 2)}{I E} \times 10, \\
S W C=\frac{F W-D W}{D W} \times 100,
\end{gathered}
$$

where $I r$ represents the water amount by the drip irrigation system (mm); $\gamma$ (gamma) is the soil bulk density $\left(1.36 \mathrm{~g} \cdot \mathrm{cm}^{-3}\right) ; \mathrm{h}$ is the depth of the soil which is irrigated in accordance with the vegetative stage; $\theta_{f c}$ is the water field capacity $(32.9 \%) ; g_{1}$ is the irrigation application rate $(\%) ; g_{2}$ is the irrigation start point (60\%); IE is the irrigation efficiency; SWC is the soil water content (\%); $F W$ is the fresh weight; and, $D W$ is the dry weight.

\section{Open and Feed Forward Irrigation Control System}

\subsection{Time Clock Scheduling and the Accumulated Radiation Method}

In greenhouses with no feedback system control (i.e., open loop system), irrigation scheduling is determined according to the grower's perspective. Usually growers use a standard irrigation dose and change the frequency of irrigation; thus, they automate irrigation only on the basis of time $[8,88]$. For soil-based greenhouse crops the irrigation frequency is usually on a daily basis under warm and sunny conditions, and every 3-4 days under cooler and cloudy conditions [28]. In soilless systems, irrigation usually starts one hour after sunrise and stops one hour before sunset, with hourly or even shorter irrigation intervals during a day under high radiation conditions. For some substrates (i.e., rockwool) night irrigation is also recommended, avoiding drying to account for crop transpiration $[105,106]$. In line with this, according to Schröder and Lieth [81], irrigation at night is advised if the moisture content of the substrate has fallen below $8 \%$ to $10 \%$ from the previous morning. However, those rules-of-thumb obviously do not apply when the weather conditions are changing quickly from day to day $[52,107]$. Lizarraga et al. [52] evaluated the efficiency of timed scheduling, and concluded that this method does not actually meet the irrigation requirements of hydroponic tomatoes resulting in over and under irrigation during the morning and in the afternoon, respectively. Similarly, Incrocci et al. [16], working with several species of ornamentals in container nursery crops, reported an increase of the water use with timed irrigation scheduling by $20 \%$ to $40 \%$ and nutrient emissions of $39 \%$ to $74 \%$ in comparison with model-based irrigation.

A more rational approach for irrigation scheduling is the accumulated radiation method, allowing more closely matched water supply to the ET rate, which is primarily a day time phenomenon depending strongly on solar radiation $[14,69,89,108,109]$. However, Shin et al. [110] indicated that the transpiration rate of soilless paprika (Capsicum annuum) plants did not proportionally increase with an increase in light intensity, especially in high light conditions.

For estimating how much energy the crop has received, a light sensor (e.g., pyranometer) is used to measure incident solar radiation. Once this has been intercepted, a threshold value of light energy, an irrigation event, is triggered. Schröder and Lieth [81] suggested light sums inside greenhouses between 0.4 and $0.6 \mathrm{MJ} \mathrm{m}^{-2}$ in closed and 1.4 and $1.8 \mathrm{MJ} \mathrm{m}^{-2}$ in open hydroponic cultures with drainage volume factors of $30 \%$ and $15 \%$, respectively. However, for rockwool substrate in a free drainage system, Lee [111] recommended accumulated values of $0.8 \mathrm{MJ} \mathrm{m}^{-2}$ with a minimum rest time set (i.e., not irrigated if the target value is reached) between $20 \mathrm{~min}$ in bright and $50 \mathrm{~min}$ on dark days according to the crop growth phase. Additionally, for bell pepper in container growth with peat mix, perlite, and pine bark media, Jovicich et al. [61] indicated that the first-quality fruit weight was enhanced at solar radiation integral levels of $0.34 \mathrm{MJ} \mathrm{m}^{-2}$, while Lizarraga et al. [52] proposed indoor values of $0.81 \mathrm{MJ} \mathrm{m}^{-2}$ for tomatoes grown in perlite in bags of $40 \mathrm{~L}$. In addition, Nikolaou et al. [60], 
working with cucumber in rockwool, indicated a 9\% lower drainage amount between high and low irrigation frequency treatments (i.e., accumulated radiation outside greenhouse $1.3 \mathrm{MJ} \mathrm{m}^{-2}$ as opposed to $3 \mathrm{MJ} \mathrm{m}^{-2}$ ), with no negative impact on production.

Despite the fact that the frequency of irrigation can be calculated based on the accumulated radiation method, the threshold values of light energy requires frequent evaluation, as affected by changes of crop coefficient values and cultivation techniques (e.g., defoliation). In any case, the solar radiation method was used only in soilless systems.

\subsection{Crop Evapotranspiration and the Water Balance Method}

Crop evapotranspiration assessment is necessary to correctly quantify crop irrigation water needs, playing a crucial role in cooling greenhouse crop canopies [112]. In order to evaluate crop evapotranspiration $\left(E T_{C}\right)$, environmental conditions and physical, morphological and physiological features of soil-plant systems have to be considered [113].

A lot of research has been conducted in the field of estimating crop water irrigation needs, in real time, similar to the initial Penman-Monteith evapotranspiration models, which were initially developed for open field cultivations. However, the majority of these studies indicated a drastic effect of different greenhouse types to the transpiration rate and the need for model recalibration in prevailing greenhouse environments [72,114]. A brief summary of the most common evapotranspiration models in different greenhouse types, from literature cited by Fazlil Ilahi [115].

Class A evaporation pans (Figure 2) are considered one of the most widely used systems for climatic measurements in the estimation of the evapotranspiration rate for open field and protected cultivation, because of their simplicity and low cost $[2,48]$. The pan has proven its practical value and has been used successfully to estimate reference evapotranspiration by observing the evaporation loss from a water surface and applying empirical coefficients to relate pan evaporation to reference evapotranspiration $\left(E T_{O}\right)[116]$.

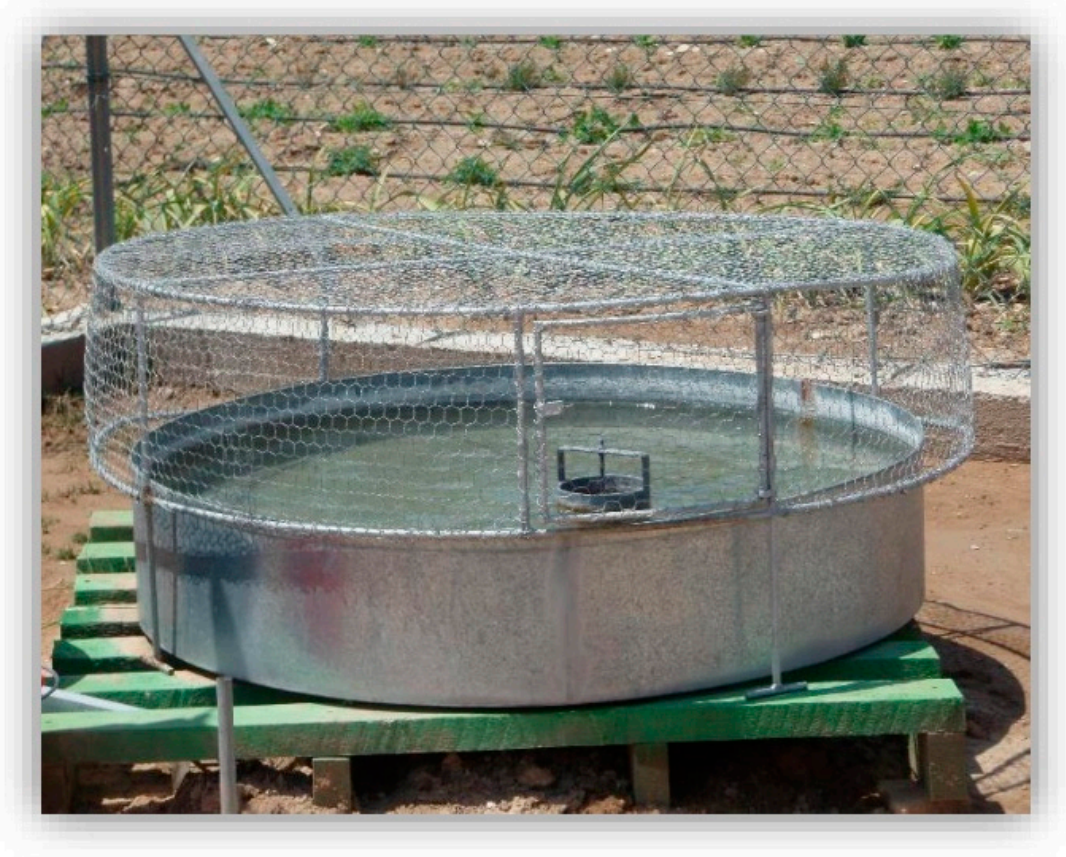

Figure 2. Class A evaporation pan.

The estimation of crop evapotranspiration with the use of a class A evaporation pan can be calculated according to Allen et al. [117].

$$
E T_{C}=E_{P} \times K_{P} \times K_{C},
$$


where $E T_{C}$ is the maximum daily crop evapotranspiration measured (mm); $E_{P}$ is the daily evaporation from class A Pan (mm); $K_{P}$ is the pan coefficient;and, $K_{C}$ is the crop coefficient.

However, there is difficulty in obtaining accurate field measurements with the use of pan A for herbaceous plants, because the crop coefficient $\left(K_{C}\right.$ value) is constantly changing throughout the growth, pruning and harvesting phases [48]. Abdel-Razzak et al. [118], working with cherry tomatoes, verified crop coefficients between 0.4 and 1.1, depending on the growth stage, while Gallardo et al. [28] indicated higher $K_{C}$ values for supporter melon (Cucumis spp.) crops in relation to non supporter types. Regarding the pan A coefficient, a constant value of 0.79 provides a good estimation of reference evapotranspiration $\left(E T_{O}\right)$ rates in plastic greenhouses under Mediterranean conditions [119], while Çakir et al. [57], working with cucumber in a solar greenhouse covered with netting material, indicated a plant-pan coefficient between 1.25 to 1.50. In line with this, for several crops in Cyprus, the evapotranspiration rate was calculated from reference evapotranspiration based on pan evaporation data, following the methodology proposed by Allen et al. [118] as indicated in Table 3 derived from Markou and Papadavid and Christou et al. [120,121]:

Table 3. Monthly and yearly estimated evapotranspiration requirements for several crops in protected cultivation (mm). Data adapted from [122,123].

\begin{tabular}{cccccccccccccc}
\hline Crop & J & F & M & A & M & J & J & A & S & O & N & D & Total \\
\hline Tomato & 42 & 60 & 85 & 120 & 180 & 168 & & & & 12 & 40 & 36 & 743 \\
\hline Cucumber & 42 & 48 & 72 & 120 & 208 & & & & & 40 & 36 & 566 \\
\hline French bean & 42 & 48 & 84 & 140 & 70 & & & & & 24 & 28 & 436 \\
\hline Aubergines & 12 & 24 & 40 & 60 & 76 & 100 & 68 & & & & & 380 \\
\hline Pepper & 12 & 24 & 40 & 60 & 76 & 100 & 112 & & & & 424 \\
\hline Watermelon & 10 & 20 & 32 & 48 & 84 & 28 & & & & & & \\
\hline Sweet melon & 10 & 20 & 32 & 48 & 84 & 28 & & & & & \\
\hline Zucchini & 12 & 24 & 50 & 78 & 136 & 88 & & & & & & & 382 \\
\hline
\end{tabular}

The estimation of reference evapotranspiration is common in China and in Japan, the use of a reduced-size $20 \mathrm{~cm}$ diameter pan, eliminating the disadvantage of the large area occupied by a class A pan, (i.e., $121 \mathrm{~cm}$ diameter) [2,109,122]. Zeng et al. [23] working in soil-based greenhouse cultivation, indicated that $K_{C P}$ values of cucumber equal to one can be recommended for the most appropriate irrigation scheduling from a standard $0.2 \mathrm{~m}$ diameter pan.

Commercially available atmometers can be used as an alternative approach to estimate evapotranspiration rate [7]. The estimated evapotranspiration values using a Piche atmometer (evaporated surface of paper disc), a modified atmometer (evaporated surface of a porous-porcelain plate) and a reduced evaporation pan were compared with the Penman-Monteith evapotranspiration method. As results indicated, atmometers had the best performance for estimating crop evapotranspiration in a greenhouse and could be used advantageously in relation to the evaporation pans [123].

According to several authors, devices that measure actual plant-soil evapotranspiration confined within containers (i.e., lysimeters) provide the only direct measure of water flux from a vegetative surface (i.e., can detect losses as small as $0.01 \mathrm{~mm}$ of water) and as such, they provide a standard against which other methods can be tested and calibrated [54,117]. Weighing lysimeters, measuring $E T_{C}$ directly through changes in mass, while drainage lysimeters calculate $E T_{C}$ through water budgets, where excess water removed by drainage or vacuum is subtracted from a known water volume applied to the soil surface [54]. In addition, Shin and Son [69] used load cells for the direct estimation of irrigation and drainage water amounts in soilless systems. Measurement practices, as cited by Sabeh [124], have ranged from weighting lysimeters measuring output every $10 \mathrm{~min}$ to calculating a 
$60 \mathrm{~min}$ average of $1 \mathrm{~min}$ measurements. However, the expense of these lysimeters limits their use to research and plants grown in containers (i.e., soilless culture systems; Figure 3) [7].
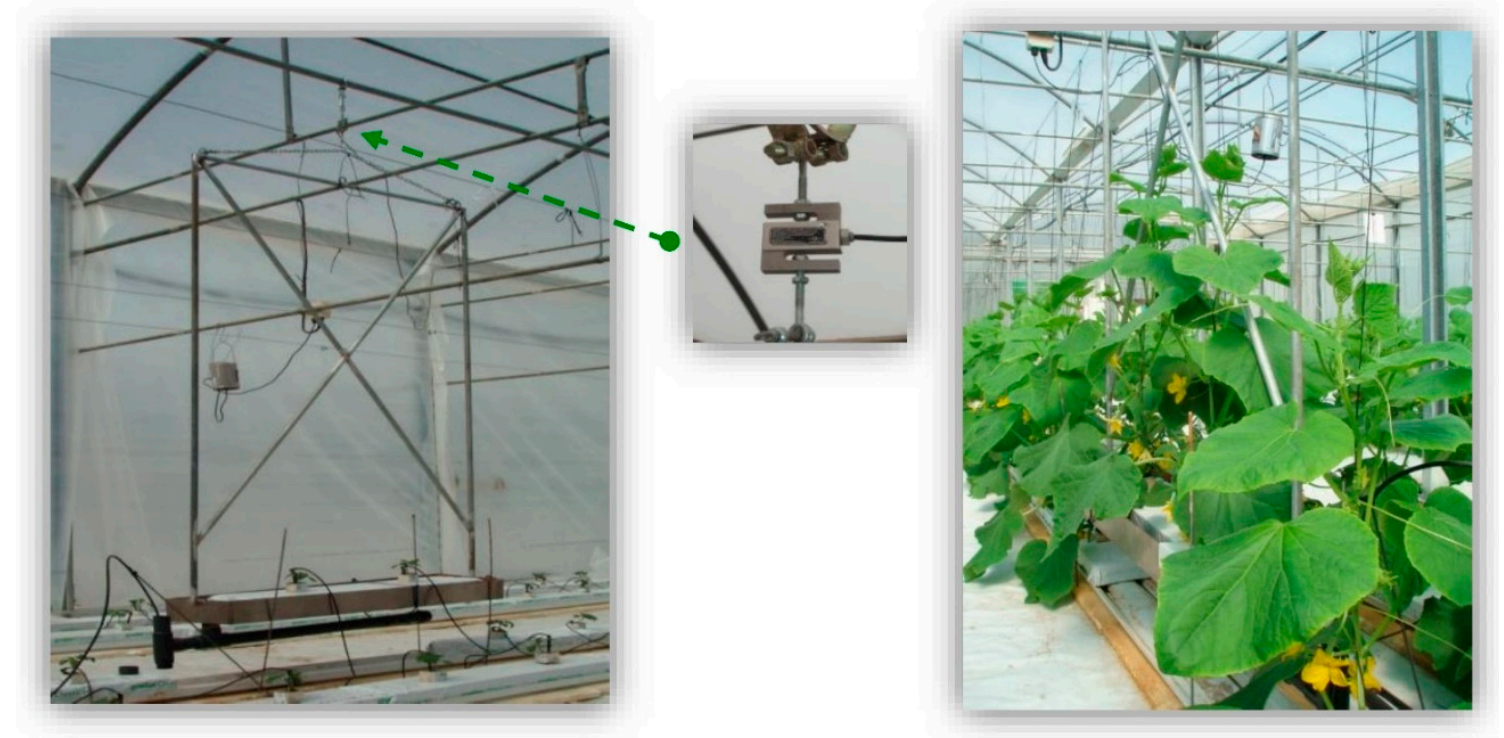

Figure 3. Mounting a lysimeter in a greenhouse structure (left), weighing device S-Beam load cell (centered) and plants grown in a lysimeter (right).

In soil-based systems simple portable scales must be replaced by expensive lysimeters. In this case sampling and representativeness problems become serious [125]. In order to eliminate this problem for soil-based greenhouse systems, it is preferable to use the water balance method, although is not very accurate, by monitoring all additions to and losses from a field's water [103]. In low volume/high frequency irrigation systems, the method has generally been sufficiently robust under a wide range of conditions [50]. Çakir et al. [57] and Mao et al. [126] estimated cucumber greenhouse crop evapotranspiration as follows:

$$
E T=I \pm \Delta \Sigma-D-R,
$$

where $E T$ is crop evapotranspiration (mm); $I$ is the total irrigation amount applied (mm); $\Delta \Sigma$ is change in soil water storage ( $\mathrm{mm}$ ); $R$ and $D$ are run-off and water loss, respectively, through deep percolation $(\mathrm{mm})$ which is assumed to be zero since the amount of irrigation water is controlled and the precipitation or discharge rate of the irrigation system is below the soil infiltration rate.

\section{Feedback Irrigation System}

\subsection{Soil/Substrate Monitoring}

The frequency of irrigation could be monitored in soilless systems by measuring the change in salt concentration inside the cultivation slab. In this case, irrigation starts when the substrate electrical conductivity increased in relation to the nutrient solution electrical conductivity to a certain limit (e.g., $0.3-1 \mathrm{~m} \cdot \mathrm{S} \cdot \mathrm{dm}^{-1}$ ) [65]. Using sensors for monitoring the EC, the $\mathrm{pH}$ and the amount of drainage could also be used as a tool for evaluating irrigation scheduling, taking into account seasonal transpiration differences [74]. As cited by Lizarraga et al. [52], the EC of the drainage solution should not be higher than $1 \mathrm{~m} \cdot \mathrm{S} \cdot \mathrm{cm}^{-1}$ compared to the EC of the irrigation solution. In addition, the percentage of the drainage amount could be tuned for irrigation control in greenhouses using a trial-end-error approach (e.g., the percentage of drainage should not be higher than $30 \%$ of the irrigation applied). Although the irrigation control system considers drainage amount as a single variable, it could not calculate the exact water amount used by the plant [69]. 
Greenhouse soil cultivation thresholds of soil potential have been used by many authors as a tool for irrigation management; even though soil matric potential values have been used, they appear to be based on experience [127]. For example, the irrigation of tomatoes and cucumbers growing in clay soils, with water potential set-points of -40 and $-30 \mathrm{kPa}$, resulted in water savings of $35 \%$ and $46 \%$, respectively, compared with irrigation set points at $-10 \mathrm{kPa}$ [128]. In line with this, for zucchini grown in artificial sand-mulched soil, a threshold soil matric potential of $-25 \mathrm{kPa}$ favored production and water savings in comparison with irrigation at -10 or $-40 \mathrm{kPa}$ [129]. On the other hand, for soilless crops, Depardieu et al. [130] indicated that plant growth and fruit production for strawberries (Fragaria $X$ ananassa) grown in organic substrate (i.e., peat-sawdust mixture, aged bark, coconut fiber) were enhanced if irrigation started at -1.0 to $-1.5 \mathrm{kPa}$, instead of -1.5 to $-2.5 \mathrm{kPa}$.

\subsection{Plant Monitoring}

Plant phyto-sensing (e.g., leaf water potential, canopy temperature, crop reflectance) has been developed for an early, quantitative detection of plant responses to actual soil water availability, in order to define in real time, irrigation strategies to maximize plant growth [131]. However, a significant limitation is the fact that they do not provide a direct measure of the irrigation volume required. Hence, plant based sensing (Figure 4) is commonly used in conjunction with other irrigation techniques such as soil moisture measurement and the water balance approach [68].
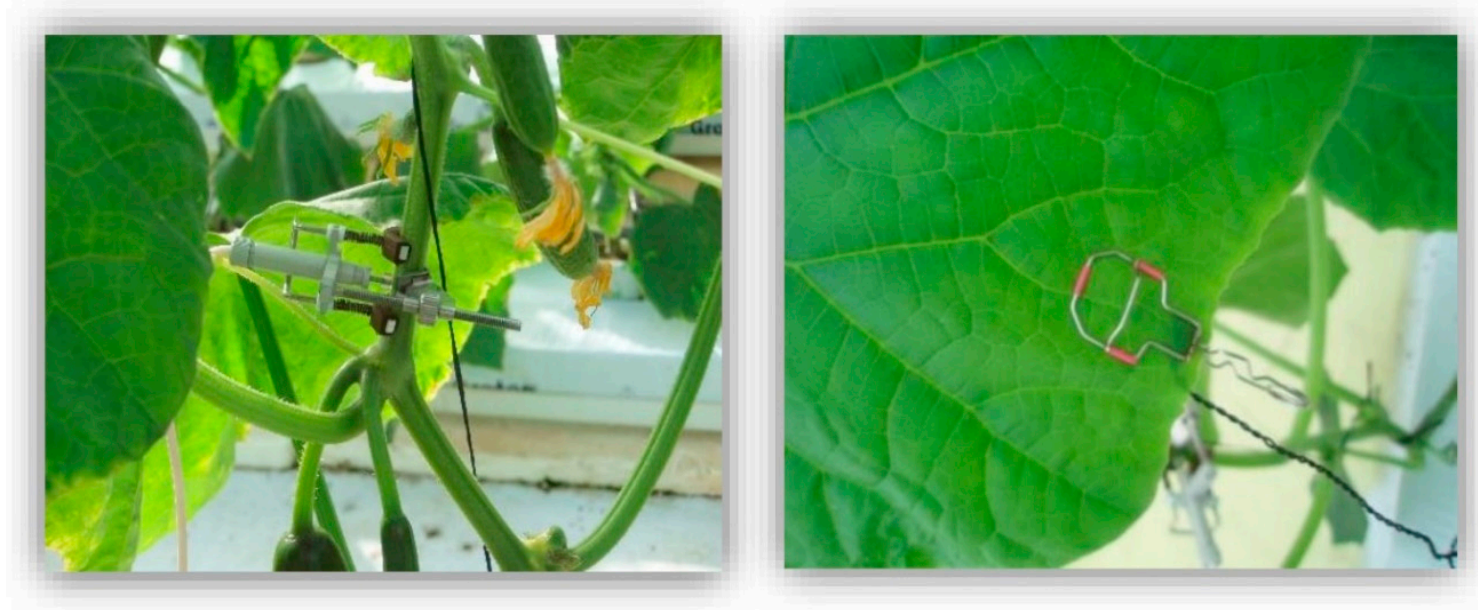

Figure 4. Stem micro-variation sensor (left) and a contact leaf temperature sensor (right).

In general, the use of plant phyto-sensing indicators as a tool for irrigation scheduling requires the estimation of reference or threshold values [50]. For example, Seelig et al. [132] used leaf thickness as an input parameter for automated irrigation control of container soil greenhouse cowpea (Vigna unguiculata) plants; indicating that $25 \%$ to $45 \%$ of irrigation water could be conserved compared with a typical timed irrigation schedule. Similarly, Nikolaou et al. [72] indicated a good correlation between leaf temperature of soilless cucumber with transpiration, and established a relationship between transpiration and leaf temperature by modified the simplified Penman-Monteith equation.

Although remote plant phyto-sensing and crop reflectance indices have been applied with great success in open fields, in greenhouses it has not yet been fully tested, as there are problems associated with greenhouse cover and structure shading [133].

The sensors and approaches used for crop reflectance measurements, and the indices used for crop water and nutrient status detection in greenhouse crops, have been reviewed by Katsoulas et al. [51]

\section{Artificial Neural Networks and Fuzzy-Logic Control Systems}

Artificial neural networks are analogue computer systems, which are made up of a large number of highly interconnected processing units which encompass computer algorithms that can 
solve several types of problems, based on different input units [134]. The use of artificial neural networks in agricultural systems is supported, as the plants' responses to their environment can be considered chaotic [135]. Until now, those systems have been applied mainly for open field cultivation, in the estimation of soil moisture content based on various soil and environmental parameters and for irrigation planning [90,136,137]. Pérez-Castro et al. [138] indicated that the water requirements within a greenhouse (i.e., evapotranspiration) can be calculated based on virtual sensors by monitoring external greenhouse climatic conditions. In line with this, virtual water sensors for soilless greenhouse tomato based on crop growth, substrate water and crop transpiration rate were also used by Sánchez-Molina et al. [139]. On the other hand Ben Ali et al. [140], developed a fuzzy logic control system in order to promote a suitable microclimate by activating the appropriate actuators installed inside the greenhouse with the appropriate rate.

Agriculture in developed countries seems to be in a transition, with increasing use of ICT (Information and Communications Technology) within the agricultural ecosystems [141]. Additionally, virtual plants have already been used to develop a case study for the irrigation processes of a greenhouse [142].

\section{Concluding Remarks}

This paper presents a review of irrigation management in soil and soilless crop production in greenhouses where irrigation scheduling should match the diurnal course of evapotranspiration as affected by the prevailing greenhouse environment through soil/substrate and crop characteristics. The majority of irrigation methods used in the past implement a feed forward or a feedback irrigation decision support system, and, in addition, water stress indices were developed based on plant-sensing. However, a gap in commercialized solutions exists despite the significant research work in the field of precision irrigation of greenhouse crops. It is important that a large margin of progress in greenhouse water and fertilizer use efficiency is managed by farmers [3]. The information presented reveals a need for the development of a commercial irrigation controller unit, in order to model and monitor the soil-plant-atmosphere utilizing artificial intelligence analyses.

Author Contributions: G.N. and D.N. conducted the literature review and produced final drafts of the manuscript. Commentary and review of manuscript drafts were conducted by N.K. and C.K.

Funding: This research received no external funding.

Conflicts of Interest: The authors declare no conflict of interest

\section{References}

1. Kittas, C.; Elvanidi, A.; Katsoulas, N.; Ferentinos, K.P.; Bartzanas, T. Reflectance indices for the detection of water stress in greenhouse tomato (Solanum lycopersicum). Acta Hortic. 2016, 1112, 63-70. [CrossRef]

2. Fernandes, C.; Corá, J.; Araújo, J. Reference evapotranspiration estimation inside greenhouses. Sci. Agric. 2003, 60, 591-594. [CrossRef]

3. Kitta, E.; Bartzanas, T.; Katsoulas, N.; Kittas, C. Benchmark irrigated under cover agriculture crops. Agric. Agric. Sci. Procedia 2015, 4, 348-355. [CrossRef]

4. Levidow, L.; Zaccaria, D.; Maia, R.; Vivas, E.; Todorovic, M.; Scardigno, A. Improving water-efficient irrigation: Prospects and difficulties of innovative practices. Agric. Water Manag. 2014, 146, 84-94. [CrossRef]

5. Bonachela, S.; González, A.M.; Fernández, M.D. Irrigation scheduling of plastic greenhouse vegetable crops based on historical weather data. Irrig. Sci. 2006, 25, 53-62. [CrossRef]

6. Lea-Cox, J.D.; Ross, D.S.; Teffeau, K.M. A Water and Nutrient Management Planning Process for Container Nursery and Greenhouse Production Systems in Maryland. J. Environ. Hortic. 2001, 19, 230-236.

7. Cahn, M.D.; Johnson, L.F. New Approaches to Irrigation Scheduling of Vegetables. Horticulturae 2017, 3 , 1-20. [CrossRef]

8. Belayneh, B.E.; Lea-Cox, J.D.; Lichtenberg, E. Costs and benefits of implementing sensor-controlled irrigation in a commercial pot-in-pot container nursery. Horttechnology 2013, 23, 760-769. [CrossRef] 
9. Qiu, R.; Kang, S.; Du, T.; Tong, L.; Hao, X.; Chen, R.; Chen, J.; Li, F. Effect of convection on the Penman-Monteith model estimates of transpiration of hot pepper grown in solar greenhouse. Sci. Hortic. 2013, 160, 163-171. [CrossRef]

10. Zimmermann, D.; Reus, R.; Westhoff, M.; Gessner, P.; Bauer, W.; Bamberg, E.; Bentrup, F.W.; Zimmermann, U. A novel, non-invasive, online-monitoring, versatile and easy plant-based probe for measuring leaf water status. J. Exp. Bot. 2008, 59, 3157-3167. [CrossRef]

11. Bacci, L.; Battista, P.; Cardarelli, M.; Carmassi, G.; Rouphael, Y.; Incrocci, L.; Malorgio, F.; Pardossi, A.; Rapi, B.; Colla, G. Modelling Evapotranspiration of Container Crops for Irrigation Scheduling. In Evapotranspiration-From Measurements to Agricultural and Environmental Applications; Gerosa, G., Ed.; IntechOpen Limited: London, UK, 2011; pp. 263-282. ISBN 978-953-307-512-9.

12. Van der Linden, A.M.A.; Hoogsteen, M.J.J.; Boesten, J.J.T.I.; Van Os, E.A.; Wipfler, E.L. Fate of Plant Protection Products in Soilless Cultivations after Drip Irrigation: Measured vs. Modelled Concentrations; National Institute for Public Health and the Environment: Bilthoven, The Netherlands, 2016; pp. 2-61.

13. Llorach-Massan, P.; Muñoz, P.; Riera, M.R.; Gabarrell, X.; Rieradevall, J.; Montero, J.I.; Villalba, G. $\mathrm{N}_{2} \mathrm{O}$ emissions from protected soilless crops for more precise food and urban agriculture life cycle assessments. J. Clean. Prod. 2017, 149, 1118-1126. [CrossRef]

14. Kläring, H.K. Strategies to control water and nutrient supplies to greenhouse crops. A review. Agronomie 2001, 21, 311-321. [CrossRef]

15. Schiattone, M.I.; Viggiani, R.; Di Venereb, D.; Sergiob, L.; Cantore, V.; Todorovic, M.; Perniola, M.; Candido, V. Impact of irrigation regime and nitrogen rate on yield, quality and water use efficiency of wild rocket under greenhouse conditions. Sci. Hortic. 2018, 229, 182-192. [CrossRef]

16. Incrocci, L.; Marzialetti, P.; Incrocci, G.; Di Vita, A.; Balendonck, J.; Bibbiani, C.; Spagnol, S.; Pardossi, A. Substrate water status and evapotranspiration irrigation scheduling in heterogenous container nursery crops. Agric. Water Manag. 2014, 131, 30-40. [CrossRef]

17. Fulcher, F.A.; Buxton, J.W.; Geneve, R.L. Developing a physiological-based, on-demand irrigation system for container production. Sci. Hortic. 2012, 138, 221-226. [CrossRef]

18. Daccache, A.; Ciurana, J.S.; Rodriguez Diaz, J.A.; Knox, J.W. Water and energy footprint of irrigated agriculture in the Mediterranean region. Environ. Res. Lett. 2014, 9, 1-12. [CrossRef]

19. Egea, G.; Fernández, J.E.; Alcon, F. Financial assessment of adopting irrigation technology for plant-based regulated deficit irrigation scheduling in super high-density olive orchards. Agric. Water Manag. 2017, 187, 47-56. [CrossRef]

20. Montesano, F.F.; Van Iersel, M.W.; Boari, F.; Cantore, V.; D'Amato, G.; Parente, A. Sensor-based irrigation management of soilless basil using a new smart irrigation system: Effects of set-point on plant physiological responses and crop performance. Agric. Water Manag. 2018, 203, 20-29. [CrossRef]

21. Pawlowski, A.; Sánchez-Molina, J.A.; Guzmán, J.L.; Rodríguez, F.; Dormido, S. Evaluation of event-based irrigation system control scheme for tomato crops in greenhouses. Agric. Water Manag. 2017, 183, 16-25. [CrossRef]

22. Sezen, S.M.; Celikel, G.; Yazar, A.; Tekin, S.; Kapur, B. Effect of irrigation management on yield and quality of tomatoes grown in different soilless media in a glasshouse. Sci. Res. Essays 2010, 5, 41-48.

23. Zeng, C.Z.; Bie, Z.L.; Yuan, B.Z. Determination of optimum irrigation water amount for drip-irrigated muskmelon (Cucumis melo L.) in plastic greenhouse. Agric. Water Manag. 2009, 96, 595-602. [CrossRef]

24. Putra, P.A.; Yuliando, H. Soilless Culture System to Support Water Use Efficiency and Product Quality: A Review. Agric. Agric. Sci. Procedia 2015, 3, 283-288. [CrossRef]

25. Montesano, F.F.; Serio, F.; Mininni, C.; Signore, A.; Parente, A.; Santamaria, P. Tensiometer-Based Irrigation Management of Subirrigated Soilless Tomato: Effects of Substrate Matric Potential Control on Crop Performance. Front. Plant Sci. 2015, 6, 1-11. [CrossRef] [PubMed]

26. Van Os, E.A.; Gieling, T.H.; Ruijs, M.N.A. Equipment for hydroponic installations. In Hydroponic Production of Vegetables and Ornamental; Savvas, D., Passam, H., Eds.; Embryo Publications: Athens, Greece, 2002; pp. 104-140. ISBN 960-8002-12-5.

27. Breś, W.; Kleiber, T.; Trelka, T. Quality of water used for drip irrigation and fertigation of horticultural plants. Folia Hortic. 2010, 22, 67-74. [CrossRef] 
28. Gallardo, M.; Thompson, R.B.; Fernández, M.D. Water requirements and irrigation management in Mediterranean greenhouses: The case of the southeast coast of Spain. In Good Agricultural Practices for Greenhouse Vegetable Crops; Plant Production and Protection Paper 217; FAO: Rome, Italy, 2013; pp. 109-136.

29. Chamindu Deepagoda, T.K.K.; Chen Lopez, J.C.; Møldrup, P.; de Jonge, L.W.; Tuller, M. Integral parameters for characterizing water, energy, and aeration properties of soilless plant growth media. J. Hydrol. 2013, 502, 120-127. [CrossRef]

30. Pardossi, A.; Carmassi, G.; Diara, C.; Incrocci, L.; Maggini, R.; Massa, D. Fertigation and Substrate Management in Closed Soilless Culture; University of Pisa, Dipartimento di Bioologia delle Piante Agrarrie (DBPA): Pisa, Italy, 2011; pp. 1-63.

31. Maślanka, M.; Magdziarz, R. The influence of substrate type and chlormequat on the growth and flowering of marigold (Tagetes L.). Folia Hortic. 2017, 29, 189-198. [CrossRef]

32. Raviv, M.; Lieth, J.M. Significance of Soilless Culture in Agriculture. In Soilless Culture. Theory and Practice; Raviv, M., Lieth, J.M., Eds.; Elsevier: Amsterdam, The Netherlands, 2008; pp. 1-10. ISBN 978-0-444-52975-6.

33. Raviv, M.; Blom, T.J. The effect of water availability and quality on photosynthesis and productivity of soilless-grown cut roses. Sci. Hortic. 2001, 88, 257-276. [CrossRef]

34. Adams, P. Nutritional control in hydroponics. In Hydroponic Production of Vegetables and Ornamental; Savvas, D., Passam., H., Eds.; Embryo Publications: Athens, Greece, 2002; pp. 211-261. ISBN 960-8002-12-5.

35. Asaduzzaman, Md.; Saifullah, Md.; Mollick, S.R.; Hossain, M.Md.; Halim, G.M.A.; Asao, T. Influence of Soilless Culture Substrate on Improvement of Yield and Produce Quality of Horticultural Crops. In Soilless Culture-Use of Substrates for the Quality Horticultural Crops; Asaduzzaman, Md., Ed.; IntechOpen Limited: London, UK, 2015; pp. 1-31.

36. Martínez-Gutiérrez, G.A.; Morales, I.; Aquino-Bolaños, T.; Escamirosa-Tinoco, C.; Hernández-Tolentino, M. Substrate volume and nursery times for earliness and yield of greenhouse tomato. Emirates J. Food Agric. 2016, 28, 897-902. [CrossRef]

37. Rouphael, Y.; Cardarelli, M.; Rea, E.; Colla, G. The influence of irrigation system and nutrient solution concentration on potted geranium production under various conditions of radiation and temperature. Sci. Hortic. 2008, 118, 328-337. [CrossRef]

38. Vox, G.; Teitel, M.; Pardossi, A.; Minuto, A.; Tinivella, F.; Schettini, E. Sustainable greenhouse systems. In Sustainable Agriculture: Technology, Planning and Management; Salazar, A., Rios, I., Eds.; Nova Science Publishers, Inc.: New York, NY, USA, 2010; pp. 1-78. ISBN 978-1-60876-269-9.

39. Warren, S.L.; Bilderback, T.E. More plant per gallon: Getting more out of your water. Horttechnology 2005, 15, 14-18. [CrossRef]

40. Leteya, J.; Hoffmanb, G.J.; Hopmansc, J.W.; Grattanc, S.R.; Suarezd, D.; Corwind, D.L.; Ostera, J.D.; Wua, L.; Amrhein, C. Evaluation of soil salinity leaching requirement guidelines Agricultural Water Management Evaluation of soil salinity leaching requirement guidelines. Agric. Water Manag. 2011, 98, 502-506. [CrossRef]

41. Baille, M.; Baille, A.; Laury, J.C. A simplified model for predicting evapotranspiration rate of nine ornamental species vs. climate factors and leaf area. Sci. Hortic. 1994, 59, 217-232. [CrossRef]

42. Ayers, R.S.; Westcot, D.W. Water Quality for Agriculture; Irrigation and Drainage Paper 29; FAO: Rome, Italy, 1985; pp. 1-131. ISBN 92-5-102263-1.

43. Ben-Gal, A.; Ityel, E.; Dudley, L.; Cohen, S.; Yermiyahu, U.; Presnov, E.; Zigmond, L.; Shani, U. Effect of irrigation water salinity on transpiration and on leaching requirements: A case study for bell peppers. Agric. Water Manag. 2008, 95, 587-597. [CrossRef]

44. Skaggs, R.K. Predicting drip irrigation use and adoption in a desert region. Agric. Water Manag. 2001, 51, 125-142. [CrossRef]

45. Rouphael, Y.; Colla, G. Growth, yield, fruit quality and nutrient uptake of hydroponically cultivated zucchini squash as affected by irrigation systems and growing seasons. Sci. Hortic. 2005, 105, 177-195. [CrossRef]

46. Harmanto; Salokhe, V.M.; Babel, M.S.; Tantau, H.J. Water requirement of drip irrigated tomatoes grown in greenhouse in tropical environment. Agric. Water Manag. 2005, 71, 225-242. [CrossRef]

47. Bianchi, A.; Masseroni, D.; Thalheimer, M.; Medici, L.O.; Facchi, A. Field irrigation management through soil water potential measurements: A review. Ital. J. Agrometeorol. 2017, 2, 25-38.

48. Nikolaou, G.; Neocleous, D.; Katsoulas, N.; Kittas, C. Irrigation management techniques used in soilless cultivation. In Advances in Hydroponic Research; Webster, D.J., Ed.; Nova Science Publishers, Inc.: New York, NY, USA, 2017; pp. 1-33. ISBN 978-1-53612-131-5. 
49. Baille, A. Water management in soilless cultivation in relation to inside and outside climatic conditions and type of substrate. Italus Hortus. 2001, 8, 16-22.

50. Jones, H.G. Irrigation scheduling: Advantages and pitfalls of plant-based methods. J. Exp. Bot. 2004, 55, 2427-2436. [CrossRef]

51. Katsoulas, N.; Elvanidi, A.; Ferentinos, K.P.; Kacira, M.; Bartzanas, T.; Kittas, C. Crop reflectance monitoring as a tool for water stress detection in greenhouses: A review. Biosyst. Eng. 2016, 151, 374-398. [CrossRef]

52. Lizarraga, A.; Boesveld, H.; Huibers, F.; Robles, C. Evaluating irrigation scheduling of hydroponic tomato in Navarra, Spain. Irrig. Drain. 2003, 52, 177-188. [CrossRef]

53. Silber, A.; Xu, G.; Levkovitch, I.; Soriano, S.; Bilu, A.; Wallach, R. High irrigation frequency: The effect on plant growth and on uptake of water and nutrients. Plant Soil 2003, 253, 466-477. [CrossRef]

54. Beeson, R.C., Jr. Weighing lysimeter systems for quantifying water use and studies of controlled water stress for crops grown in low bulk density substrates. Agric. Water Manag. 2011, 98, 967-976. [CrossRef]

55. Libardi, L.G.P.; de Faria, R.T.; Dalri, A.B.; de Souza Rolim, G.; Palaretti, L.F.; Coelho, A.P.; Martins, I.P. Evapotranspiration and cropcoefficient $(\mathrm{Kc})$ of presprouted sugarcane plantlets for greenhouse irrigation management. Agric. Water Manag. 2019, 212, 306-316. [CrossRef]

56. Vera-Repulloa, J.A.; Ruiz-Peñalverb, L.; Jiménez-Buendíaa, M.; Rosillob, J.J.; Molina-Martínez, J.M. Software for the automatic control of irrigation using weighing-drainage lysimeters. Agric. Water Manag. 2015, 151, 4-12. [CrossRef]

57. Çakir, R.; Kanburoglu-Çebi, U.; Altintas, S.; Ozdemir, A. Irrigation scheduling and water use efficiency of cucumber grown as a spring-summer cycle crop in solar greenhouse. Agric. Water Manag. 2017, 180, 78-87. [CrossRef]

58. Abou-Hadid, A.F.; El-Shinawy, M.Z.; El-Oksh, I.; Gomaa, H.; El-Beltagy, A.S. Studies on Water Consumption of Sweet Pepper Plant Under Plastic Houses. Acta Hortic. 1994, 366, 365-372. [CrossRef]

59. Zhang, C.; Gao, H.; Deng, X.; Lu, Z.; Lei, Y.; Zhou, H. Design method and theoretical analysis for wheel-hub driving solar tractor. Emirates J. Food Agric. 2016, 28, 903-911. [CrossRef]

60. Nikolaou, G.; Neocleous, D.; Katsoulas, N.; Kittas, C. Effect of irrigation frequency on growth and production of a cucumber crop under soilless culture. Emirates J. Food Agric. 2017, 29, 863-871. [CrossRef]

61. Jovicich, E.; Cantliffe, D.J.; Stoffella, P.J.; Haman, D.Z. Bell pepper fruit yield and quality as influenced by solar radiation-based irrigation and container media in a passively ventilated greenhouse. HortScience 2007, 42, 642-652.

62. Pardossi, A.; Incrocci, L.; Incrocci, G.; Fernando, M.; Bacci, L.; Rapi, B.; Marzialetti, P.; Hemming, J.; Balendonck, J. Root Zone Sensors for Irrigation Management in Intensive Agriculture. Sensors 2009, 9, 2809-2835. [CrossRef] [PubMed]

63. Nemali, K.S.; Montesano, F.; Dove, S.K.; Van Iersel, M.W. Calibration and performance of moisture sensors in soilless substrates: $\mathrm{ECH}_{2} \mathrm{O}$ and Theta probes. Sci. Hortic. 2007, 112, 227-234. [CrossRef]

64. Murray, J.D.; Lea-Cox, J.D.; Ross, D.S. Time domain reflectometry accurately monitors and controls irrigation water applications in soilless substrates. Acta Hortic. 2004, 633, 75-82. [CrossRef]

65. Mavrogianopoulos, G.N. Irrigation dose according to substrate characteristics, in hydroponic systems. Open Agric. 2015, 1, 1-6. [CrossRef]

66. Dorai, M.; Papadopoulos, A.P.; Gosselin, A. Influence of electric conductivity management on greenhouse tomato yield and fruit quality. Agronomie 2001, 4, 367-383. [CrossRef]

67. Liopa-Tsakalidi, A.; Barouchas, P.; Salahas, G. Response of Zucchini to the Electrical Conductivity of the Nutrient Solution in Hydroponic Cultivation. Agric. Agric. Sci. Procedia 2015, 4, 459-462. [CrossRef]

68. White, S.; Raine, S.R. A Grower Guide to Plant Based Sensing for Irrigation Scheduling; National Centre for Engineering in Agriculture Publication 1001574/6; USQ: Toowoomba, Australia, 2008; pp. 1-52.

69. Shin, J.H.; Son, J.E. Development of a real-time irrigation control system considering transpiration, substrate electrical conductivity, and drainage rate of nutrient solutions in soilless culture of paprika (Capsicum annuum L.). Eur. J. Hortic. Sci. 2015, 80, 271-279. [CrossRef]

70. Nikolaou, G.; Neocleous, D.; Katsoulas, N.; Kittas, C. Dynamic assessment of whitewash shading and evaporative cooling on the greenhouse microclimate and cucumber growth in a Mediterranean climate. Ital. J. Agrometeorol. 2018, 2, 15-26.

71. Prenger, J.J.; Ling, P.P.; Hansen, R.C.; Keener, H.H. Plant response-based irrigation in a greenhouse: System evaluation. Trans. ASAE Am. Soc. Agric. Eng. 2005, 48, 1175-1183. [CrossRef] 
72. Nikolaou, G.; Neocleous, D.; Katsoulas, N.; Kittas, C. Modelling transpiration of soilless greenhouse cucumber and its relationship with leaf temperature in a mediterranean climate. Emirates J. Food Agric. 2017, 29, 911-920. [CrossRef]

73. De Swaef, T.; Steppe, K. Linking stem diameter variations to sap flow, turgor and water potential in tomato. Funct. Plant Biol. 2010, 37, 429-438. [CrossRef]

74. Ehret, D.L.; Lau, A.; Bittman, S.; Lin, W.; Shelford, T. Automated monitoring of greenhouse crops. Agronomie 2001, 21, 403-414. [CrossRef]

75. Kim, M.; Kim, S.; Kim, Y.; Choi, Y.; Seo, M. Infrared Estimation of Canopy Temperature as Crop Water Stress Indicator. Korean J. Soil Sci. Fertil. 2015, 48, 499-504. [CrossRef]

76. Nuruddin, M.; Madramootoo, C.A.; Dodds, G.T. Effects of Water Stress at Different Growth Stages on Greenhouse Tomato Yield and Quality. HortScience 2003, 38, 1389-1393.

77. Alomran, A.M.; Louki, I.I.; Aly, A.A.; Nadeem, M.E. Impact of deficit irrigation on soil salinity and cucumber yield under greenhouse condition in an arid environment. J. Agric. Sci. Technol. 2013, 15, 1247-1259.

78. Saleh, S.; Liu, G.; Liu, M.; Ji, Y.; He, H.; Gruda, N. Effect of Irrigation on Growth, Yield, and Chemical Composition of Two Green Bean Cultivars. Horticulturae 2018, 4, 1-10. [CrossRef]

79. Saha, U.K.; Papadopoulos, A.P.; Hao, X.; Khosla, S. Irrigation strategies for greenhouse tomato production on rockwool. HortScience 2008, 43, 484-493.

80. Zegbe, J.A.; Behboudian, M.H.; Clothier, B.E. Yield and fruit quality in processing tomato under partial rootzone drying. Eur. J. Hortic. Sci. 2006, 71, 252-258.

81. Schröder, F.G.; Lieth, J.H. Irrigation control in hydroponics. In Hydroponic Production of Vegetables and Ornamentals; Savvas, D., Passam, H., Eds.; Embryo Publications: Athens, Greece, 2002; pp. 263-297. ISBN 960-8002-12-5.

82. Katsoulas, N.; Kittas, C.; Dimokas, G.; Lykas, C. Effect of irrigation frequency on rose flower production and quality. Biosyst. Eng. 2006, 93, 237-244. [CrossRef]

83. Pires, R.C.M.; Furlani, P.R.; Ribeiro, R.V.; Bodine, J.; Décio, S.; Emílio, L.; André, L.; Torre Neto, A. Irrigation frequency and substrate volume effects in the growth and yield of tomato plants under greenhouse conditions. Sci. Agric. 2011, 68, 400-405. [CrossRef]

84. Rodriguez-Ortega, W.M.; Martinez, V.; Rivero, R.M.; Camara-Zapata, J.M.; Mestre, T.; Garcia-Sanchez, F. Use of a smart irrigation system to study the effects of irrigation management on the agronomic and physiological responses of tomato plants grown under different temperatures regimes. Agric. Water Manag. 2016, 183, 158-168. [CrossRef]

85. Tsirogiannis, I.; Katsoulas, N.; Kittas, C. Effect of irrigation scheduling on gerbera flower yield and quality. HortScience 2010, 45, 265-270.

86. Romero, R.; Muriel, J.L.; García, I.; Muñoz de la Peña, D. Research on automatic irrigation control: State of the art and recent results. Agric. Water Manag. 2012, 114, 59-66. [CrossRef]

87. Challa, H.; Bakker, J.C. Crop growth. In Greenhouse Climate Control: An Integrated Approach; Bakker, J.C., Bot, G.P.A., Challa, H., Van de Braak, N.J., Eds.; Wageningen Academic Publishers: Wageningen, The Netherlands, 1995; pp. 15-97. ISBN 978-90-74134-17-0.

88. Lea-Cox, J.D.; Bauerle, W.L.; Van Iersel, M.W.; Kantor, G.F.; Bauerle, T.L.; Lichtenberg, E.; King, D.M.; Crawford, L. Advancing wireless sensor networks for irrigation management of ornamental crops: An overview. Horttechnology 2013, 23, 717-724. [CrossRef]

89. Shelford, T.J.; Lau, A.K.; Ehret, D.L.; Chieng, S.T. Comparison of a new plant-based irrigation control method with light-based irrigation control for greenhouse tomato production. Can. Biosyst. Eng. 2004, 4, 1-6.

90. Raju, K.S.; Kumar, D.N. Multicriterion decision making in irrigation planning. Irrig. Drain. 2005, 54, 455-465. [CrossRef]

91. Londra, P.A. Simultaneous determination of water retention curve and unsaturated hydraulic conductivity of substrates using a steady-state laboratory method. HortScience 2010, 45, 1106-1112.

92. Bougoul, S.; Boulard, T. Water dynamics in two rockwool slab growing substrates of contrasting densities. Sci. Hortic. 2006, 107, 399-404. [CrossRef]

93. Schindler, U.; Müller, L.; Eulenstein, F. Hydraulic Performance of Horticultural Substrates-1. Method for Measuring the Hydraulic Quality Indicators. Horticulturae 2017, 3, 1-7. [CrossRef]

94. Altland, J.E.; Owen, J.S.; Fonteno, W.C. Developing Moisture Characteristic Curves and Their Descriptive Functions at Low Tensions for Soilless Substrates. J. Amer. Soc. Hortic. Sci. 2010, 135, 563-567. 
95. Fields, J.S.; Fonteno, W.C.; Jackson, B.E.; Heitman, J.L.; Owen, J.S. Hydrophysical properties, moisture retention, and drainage profiles of wood and traditional components for greenhouse substrates. HortScience 2014, 49, 827-832.

96. De Pascale, S.; Barbieri, G.; Rouphael, Y.; Gallardo, M.; Orsini, F.; Pardossi, A. Irrigation management: Challenges and opportunities. In Good Agricultural Practices for Greenhouse VEGETABLE production in the South East European Countries for Greenhouse Vegetable; Plant Production and Protection Paper 230; FAO: Rome, Italy, 2013; pp. 79-105.

97. Raviv, M.; Wallach, R.; Silber, A.; Medina, S.; Krasnovsky, A. The effect of hydraulic characteristics of volcanic materials on yield of roses grown in soilless culture. J. Am. Soc. Hortic. Sci. 1999, 124, 205-209.

98. Hosseini, S.M.M.M.; Ganjian, N.; Pisheh, Y.P. Estimation of the water retention curve for unsaturated clay. Can. J. Soil Sci. 2011, 91, 543-549. [CrossRef]

99. Bilderback, T.E.; Warren, S.L.; Owen, J.S.; Albano, J.P. Healthy Substrates Need Physicals Too! Horttechnology 2005, 15, 747-751. [CrossRef]

100. Nowak, J.S. Changes of Physical Properties in Rockwool and Glasswool Slabs During Hydroponic Cultivation of Roses. J. Fruit Ornam. Plant Res. 2010, 18, 349-360.

101. Jones, H.G.; Tardieu, F. Modelling water relations of horticultural crops: A review. Sci. Hortic. 1998, 74, 21-46. [CrossRef]

102. De Jong van Lier, Q. Field capacity, a valid upper limit of crop available water? Agric. Water Manag. 2017, 193, 214-220. [CrossRef]

103. Snyder, R.L. Irrigation Scheduling: Water Balance Method; University of California, Department of Land, Air and Water Resources Atmospheric Science Davis: Berkeley, CA, USA, 2014; pp. 1-39.

104. Greenwood, D.J.; Zhang, K.; Hilton, H.W.; Thompson, A.J. Opportunities for improving irrigation efficiency with quantitative models, soil water sensors and wireless technology. J. Agric. Sci. 2010, 148, 1-16. [CrossRef]

105. Carmassi, G.; Bacci, L.; Bronzini, M.; Incrocci, L.; Maggini, R.; Bellocchi, G.; Massa, D.; Pardossi, A. Modelling transpiration of greenhouse gerbera (Gerbera jamesonii $\mathrm{H}$. Bolus) grown in substrate with saline water in a Mediterranean climate. Sci. Hortic. 2013, 156, 9-18. [CrossRef]

106. Medrano, E.; Lorenzo, P.; Sánchez-Guerrero, M.C.; Montero, J.I. Evaluation and modelling of greenhouse cucumber-crop transpiration under high and low radiation conditions. Sci. Hortic. 2005, 105, 163-175. [CrossRef]

107. Andrew, L.; Enthoven, N.; Kaarsemaker, R. Best Practice Guidelines for Greenhouse Water Management; GRODAN \& Priva: Roermond, The Netherlands, 2016; pp. 1-38.

108. Kittas, C. Solar radiation of a greenhouse as a tool to its irrigation control. Int. J. Energy Res. 1990, 14, 881-892. [CrossRef]

109. Zhang, Z.K.; Liu, S.Q.; Liu, S.H.; Huang, Z.J. Estimation of Cucumber Evapotranspiration in Solar Greenhouse in Northeast China. Agric. Sci. China 2010, 9, 512-518. [CrossRef]

110. Shin, J.H.; Park, J.S.; Son, J.E. Estimating the actual transpiration rate with compensated levels of accumulated radiation for the efficient irrigation of soilless cultures of paprika plants. Agric. Water Manag. 2014, 135, 9-18. [CrossRef]

111. Lee, A. Reducing or eliminating fruit physiological disorders with correct root zone management. Practical Hydroponics \& Greenhouses, May/June 2010; 53-59.

112. Katsoulas, N.; Kittas, C. Greenhouse Crop Transpiration Modelling. In Evapotranspiration—From Measurements to Agricultural and Environmental Applications; Gerosa, G., Ed.; IntechOpen Limited: London, UK, 2011; pp. 311-328. ISBN 978-953-307-512-9.

113. Lovelli, S.; Perniola, M.; Arcieri, M.; Rivelli, R.; Di Tommaso, T. Water use assessment in muskmelon by the Penman-Monteith 'one-step' approach. Agric. Water Manag. 2008, 95, 1153-1160. [CrossRef]

114. Morille, B.; Migeon, C.; Bournet, P.E. Is the Penman-Monteith model adapted to predict crop transpiration under greenhouse conditions? Application to a New Guinea Impatiens crop. Sci. Hortic. 2013, 152, 80-91. [CrossRef]

115. Fazlil Ilahi, W.F. Evapotranspiration Models in Greenhouse. Master's Thesis, Irrigation and Water Engineering Group, Wageningen University, Wageningen, The Netherlands, 2009; pp. 1-52.

116. Simba, F.M. A Flexible Plant Based Irrigation Control for Greenhouse Crops. A Thesis submitted in partial fulfillment for the requirements of the Master of Science, University of Zimbabwe, Harare, Zimbabwe, 2010. 
117. Allen, R.; Pereira, L.; Raes, D.; Smith, M. Crop Evapotranspiration Guidelines for Computing Crop Water Requirements; FAO Irrigation and Drainage Paper, 56; FAO: Rome, Italy, 1998; pp. 1-289.

118. Abdel-Razzak, H.; Wahb-Allah, M.; Ibrahim, A.; Alenazi, M.; Alsadon, A. Response of cherry tomato to irrigation levels and fruit pruning under greenhouse conditions. J. Agric. Sci. Technol. 2016, 18, 1091-1103.

119. Fernández, M.D.; Bonachela, S.; Orgaz, F.; Thompson, R.; López, J.C.; Granados, M.R.; Gallardo, M.; Fereres, E. Measurement and estimation of plastic greenhouse reference evapotranspiration in a Mediterranean climate. Irrig. Sci. 2010, 28, 497-509. [CrossRef]

120. Markou, M.; Papadavid, G. Norm input -output data for the main crop and livestock enterprises of Cyprus. Agric. Econ. 2007, 46, 0379-0827.

121. Christou, A.; Dalias, P.; Neocleous, D. Spatial and temporal variations in evapotranspiration and net water requirements of typical Mediterranean crops on the island of Cyprus. J. Agric. Sci. 2017, 1, 1188-1197. [CrossRef]

122. Liu, H.J.; Cohen, S.; Tanny, J.; Lemcoff, J.H.; Huang, G. Estimation of banana (Musa sp.) plant transpiration using a standard $20 \mathrm{~cm}$ pan in a greenhouse. Irrig. Drain. Syst. 2008, 22, 311-323. [CrossRef]

123. Blanco, F.F.; Folegatti, M.V. Evaluation of evaporation measuring-equipments for estimating evapotranspiration within a greenhouse evapotranspiranspiration greenhouse. Revista Brasileira de Engenharia Agrícola e Ambiental. 2004, 8, 184-188. [CrossRef]

124. Sabeh, N.C. Evaluating and minimizing water use by greenhouse evaporative cooling systems in a semi-arid climate. In Partial Fulfillment of the Requirements for the Degree of Doctor of Philosophy; University of Arizona: Tucson, AZ, USA, 2007.

125. Seginer, I.; Kantz, D.; Levav, N.; Peiper, U.M. Night-time transpiration in greenhouses. Sci. Hortic. 1990, 41, 265-276. [CrossRef]

126. Mao, X.; Liu, M.; Wang, X.; Liu, C.; Hou, Z.; Shi, J. Effects of deficit irrigation on yield and water use of greenhouse grown cucumber in the North China Plain. Agric. Water Manag. 2003, 61, 219-228. [CrossRef]

127. Thompson, R.B.; Gallardo, M.; Valdez, L.C.; Fernández, M.D. Using plant water status to define threshold values for irrigation management of vegetable crops using soil moisture sensors. Agric. Water Manag. 2007, 88, 147-158. [CrossRef]

128. Buttaroa, D.; Santamariab, P.; Signoreb, A.; Cantorea, V.; Boari, F.; Montesano, F.F.; Parente, A. Irrigation Management of Greenhouse Tomato and Cucumber Using Tensiometer: Effects on Yield, Quality and Water Use. Agric. Agric. Sci. Procedia 2015, 4, 440-444. [CrossRef]

129. Contreras, J.I.; Alonso, F.; Cánovas, G.; Baeza, R. Irrigation management of greenhouse zucchini with different soil matric potential level. Agronomic and environmental effects. Agric. Water Manag. 2017, 183, $26-34$. [CrossRef]

130. Depardieu, C.; Prémont, V.; Boily, C.; Caron, J. Sawdust and bark-based substrates for soilless strawberry production: Irrigation and electrical conductivity management. PLoS ONE. 2016, 11, e0154104. [CrossRef] [PubMed]

131. Gurovich, L.A.; Ton, Y.; Vergara, L.M. Irrigation scheduling of avocado using phytomonitoring techniques. Cienc. E Investig. Agrar. 2006, 33, 117-124.

132. Seelig, H.-D.; Stoner, R.J.; Linden, J.C. Irrigation control of cowpea plants using the measurement of leaf thickness under greenhouse conditions. Irrig. Sci. 2012, 30, 247-257. [CrossRef]

133. Sarlikioti, V.; Meinen, E.; Marcelis, L.F.M. Crop Reflectance as a tool for the online monitoring of LAI and PAR interception in two different greenhouse Crops. Biosyst. Eng. 2011, 108, 114-120. [CrossRef]

134. Ozcep, F.; Yıldırım, E.; Tezel, O.; Asci, M.; Karabulut, S. Correlation between electrical resistivity and soil-water content based artificial intelligent techniques. Int. J. Phys. Sci. 2010, 5, 47-56.

135. Morimoto, T.; Hashimoto, Y. An Intelligent Control Technique Based on Fuzzy Controls, Neural Networks and Genetic Algorithms for Greenhouse Automation. IFAC Artif. Intell. Agnculture 1998, 31, 61-66. [CrossRef]

136. Mohapatra, A.G.; Lenka, S.K. Neural Network Pattern Classification and Weather Dependent Fuzzy Logic Model for Irrigation Control in WSN Based Precision Agriculture. Phys. Procedia 2016, 78, 499-506. [CrossRef]

137. Saylan, L.; Kimura, R.; Caldag, B.; Akalas, N. Modeling of Soil Water Content for Vegetated Surface by Artificial Neural Network and Adaptive Neuro-Fuzzy Inference System. Ital. J. Agrometeorol. 2017, 22, 37-44.

138. Pérez-Castro, A.; Sánchez-Molina, J.A.; Castilla, M.; Sánchez-Moreno, J.; Moreno-Úbeda, J.C.; Magán, J.J. cFertigUAL: A fertigation management app for greenhouse vegetable crops. Agric. Water Manag. 2017, 183, 186-193. [CrossRef] 
139. Sánchez-Molina, J.A.; Rodríguez, F.; Guzmán, J.L.; Ramírez-Arias, J.A. Water content virtual sensor for tomatoes in coconut coir substrate for irrigation control design. Agric. Water Manag. 2015, 151, 114-125. [CrossRef]

140. Ben Ali, R.; Bouadila, S.; Mami, A. Development of a Fuzzy Logic Controller applied to an agricultural greenhouse experimentally validated. Appl. Therm. Eng. 2018, 141, 798-810. [CrossRef]

141. Guirado-Clavijo, R.; Sanchez-Molina, J.A.; Wang, H.; Bienvenido, F. Conceptual Data Model for IoT in a Chain-Integrated Greenhouse Production: Case of the Tomato Production in Almeria (Spain). IFAC-PapersOnLine 2018, 51, 102-107. [CrossRef]

142. Rodríguez, F.; Castilla, M.; Sánchez, J.A.; Pawlowski, A. Semi-virtual Plant for the Modeling Control and Supervision of batch-processes. An example of a greenhouse irrigation system. IFAC-PapersOnLine 2015, 48, 123-128. [CrossRef]

(C) 2019 by the authors. Licensee MDPI, Basel, Switzerland. This article is an open access article distributed under the terms and conditions of the Creative Commons Attribution (CC BY) license (http://creativecommons.org/licenses/by/4.0/). 